\title{
Indonesia's Global Maritime Axis Doctrine: Security Concerns and Recommendations
}

\author{
Dewi Santoso \& Fadhillah Nafisah \\ Universitas Airlangga
}

\begin{abstract}
Since President Joko Widodo's administration begins, there has been a new reform for Indonesia's maritime psyche. The President sees a huge potential in Indonesia's maritime sector, especially due to its strong and consolidated domain around Indian and Pacific Oceans. Hence, he came up with an overarching concept of "Global Maritime Axis", and set it as the main point of his administration. This so-called "Jokowi's doctrine" fundamentally represents national vision and development agenda to rebuild the country's identity as a maritime nation, boosts its maritime culture, and expands its economy from which Indonesians could prosper. This paper seeks to analyze the impact of Indonesia's maritime vision in foreign and defense policy, specifically upon maritime diplomacy and resolutions of border disputes; maintenance of territorial integrity, maritime sovereignty, good order at sea, security over the outer islands; and safeguards over national resources and exclusive economic zones (EEZ). It then ends with examining recent maritime security developments, which fosters Indonesia's position as a maritime power with considerable diplomatic influence on the world, and the opportunities therein.
\end{abstract}

Keywords: maritime security, global maritime axis, territorial sovereignty, maritime diplomacy.

Sejak pemerintahan Presiden Joko Widodo dimulai, terdapat reformasi baru bagi jiwa maritim indonesia. Presiden melihat potensi yang sangat besar di sektor maritim indonesia, terutama karena wilayah yang kuat dan terkonsolidasi dalam Samudera Hindia dan Pasifik. Oleh karena itu, beliau mengemukakan konsep menyeluruh tentang "poros maritim dunia", dan menetapkannya sebagai titik utama pemerintahannya. Inilah "Doktrin Jokowi" yang pada dasarnya merupakan agenda visi dan pengembangan nasional untuk membangun kembali identitas negara sebagai negara maritim, meningkatkan budaya maritimnya, dan memperluas ekonominya demi kesejahteraan bangsa Indonesia. Tulisan ini bertujuan untuk menganalisis dampak visi maritim indonesia dalam kebijakan luar negeri dan pertahanan, khususnya mengenai diplomasi maritim dan resolusi sengketa perbatasan; pemeliharaan integritas teritorial, kedaulatan maritim, ketertiban baik di laut, keamanan di luar pulau; dan pengamanan sumber daya nasional dan zona ekonomi eksklusif (EEZ). Kemudian berakhir dengan memeriksa perkembangan keamanan maritim baru-baru ini, yang mendorong Indonesia untuk menjadi kekuatan maritim dengan pengaruh diplomatik yang cukup besar bagi dunia, dan peluang di dalamnya.

Kata-kata kunci: keamanan maritim, poros maritim dunia, kedaulatan teritorial, diplomasi maritim. 
History witnessed that "whoever controls the sea, rules the world". For years, the West has been dominating the maritime sector, as well as world's economy. However, Indonesia realizes that a substantial transformation is taking place in the current 21st century. The world has witnessed a tectonic change in global and regional power relations. The center of economic and political gravity is shifting from West to East. Asian countries are on the rise. Indonesia sees this as a huge potential. Since President Joko Widodo's administration began, there has been a new reform to Indonesia's maritime psyche. The president sees a huge potential in Indonesia's maritime sector, especially due to its strong and consolidated domain around Indian and Pacific Oceans. Therefore, during the East Asia Summit Meeting in November 2014, the President first unveiled his overarching concept to turn Indonesia into a "Global Maritime Axis". It fundamentally represents a national vision and development agenda to rebuild Indonesia's maritime culture and expand its economy. The concept also signifies a new strategic doctrine that projects Indonesia to become a huge maritime power with considerable diplomatic influence. Specifically, due to its strategic geo- location, Indonesian is projected to play a central and dominant role in fostering regional and global economy.

As the world's largest archipelagic state, with over 17,000 islands and 6 million square kilometers of maritime area under its jurisdiction, and located at the cross roads of to major maritime worlds, it is about time that Indonesia asserts itself as the World's Maritime Axis, Jokowi's maritime doctrine, which is bold and unprecedented, is vital for Indonesia's future. (Witular, 2014). It sets aside the prehistoric belief that being an archipelagic state is a disadvantage; instead, should be re-interpreted as a blessing on counts of its immense maritime opportunities. The central idea of his maritime doctrine, to the President, is to foster the country's maritime identity. Reasserting the long -standing "archipelagic outlook", Indonesian people must value the waters surrounding the archipelago for its economic potential and national strength, rather than deeming it as a natural disadvantage. It is worth to note that in the past, Indonesia was a respectful maritime power for more than 800 years. The famous Sriwijaya kingdom (8th - 12th century) was a huge maritime power from Sumatera, while the Majapahit Kingdom (13th to 15th century) was another influential maritime power from Java. History acknowledged Nusantara as a dominant player in the 
"Laut Selatan". Thus, as a maritime country, Indonesia's inherited strategic footing opens up opportunities to develop regional and international cooperation for the prosperity of its people.

The doctrine of Global Maritime Axis is a vision of Indonesia to become a sovereign, advanced, independent, and strong maritime country, which contributes positively to peace and security of the region, and of the world, in accordance with its national interest. This new doctrine extends Indonesia's sphere from being ASEANcentered to a much bigger Indo-Pacific region, and ultimately encompasses the whole globe. It aims to ensure inter-island connectivity, development of shipping and fishery industries, improvement of marine transportation, a focus on maritime security, and a bigger role for Indonesia in regional and global diplomacy. Jokowi affirms Five Main Pillars towards the Global Maritime Axis. The first pillar is rebuilding Indonesia's maritime culture. As a country that is made up of 17,000 islands, the nation must realize that its future is largely determined by how it manages the oceans. Secondly, Indonesia shall maintain and manage sea resources with a focus on establishing sovereignty over sea-based food products. Thirdly, the country should prioritize infrastructure and maritime connectivity development by building sea tolls and deep-sea ports while also improving the shipping industry, logistics, and maritime tourism. Fourthly, through maritime diplomacy, Indonesia must end the sources of conflict at sea, such as illegal fishing, violation of sovereignty, territorial disputes, piracy and pollution. Finally, As a country intersecting two oceans, Indonesia is obligated to enhance its maritime defense power (The Jakarta Post, 2017).

Nevertheless, the realization of Indonesia's novel maritime doctrine primarily requires strong maintenance of maritime security to ensure national sovereignty and regional safety. Issues of illegal fishing, smuggling, and piracy at sea are particularly salient within the archipelagic state. The persisting territorial disputes over Natuna water have led to rising maritime tensions and intensified power rivalries with its neighboring coastal states. These matters remain at the forefront of Indonesia's maritime security concerns (Prianto, 2016).

This paper seeks to analyze the impact of Indonesia's maritime vision in foreign and defense policy, specifically upon maritime 
diplomacy and resolutions of border disputes; maintenance of territorial integrity, maritime sovereignty, good order at sea, security over the outer islands; and safeguards over national resources and exclusive economic zones ('EEZ'). It then ends with examining recent maritime security developments, which fosters Indonesia to become a respectable maritime power with considerable diplomatic influence to the world, and the opportunities therein.

\section{Ilegal, Unreported and Unregulated Fishing}

As the largest, and, undeniably, most important country in the Western Pacific region when it comes to marine resources, Indonesia waters contain some of the highest marine biodiversity on the planet. Seventy-six of it encompass known marine species, such as shrimp, tuna, crab, and squid, and those species are among the most valuable exports, which accounted for more that USD $\$ 3$ billion in export value each year, and contributes $22 \%$ to national GDP (Reveron, 2016). Despite Indonesia's existing regulations, which cover coastal and maritime resource managements, but in reality there is a high degree of non-compliant behavior. Indonesia marine resources are threatened primarily by activities of illegal, unreported and unregulated fishing ('IUU Fishing'). There has been widespread illegal fishing in major Indonesian coastal areas, especially those bordering nearby states. Depleted fish stock in Southeast Asia has led foreign fishing fleets to venture into the territory of others, creating tensions between Indonesia and its neighbors. Even further, the IUU Fishing caused at least $\$ 6$ billion loss, thus, to respond to this problem, President Widodo has ordered a daring measure of sinking foreign fishing boats that unlawfully enter Indonesian territorial waters - part of what Jokowi described as a "shock therapy". In 2014, for instance, Indonesian marine law enforcement authorities have sunk at least 84 foreign fishing vessels and confiscated over a hundred foreign vessels for poaching fish in Indonesian waters (The Jakarta Globe, 2014). 
Figure 1: Table of Captured IUU Fishing Vessels (2008 - 2014)

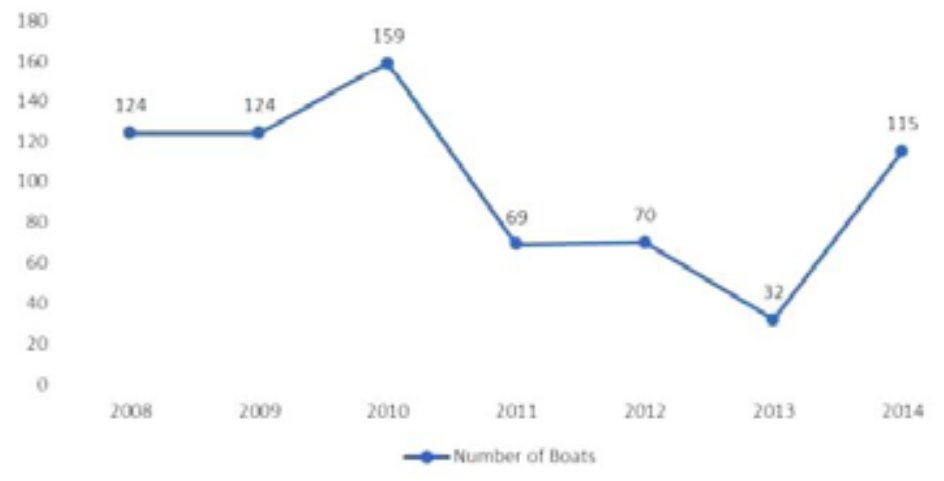

Source: Ministry of Marine and Fishery

In an attempt to downplay regional criticisms, Jokowi's administration has repeatedly stressed that the presidential directive complied with existing national laws, and insisted that Indonesia has no other choice but to employ this approach to safeguard its rights (Hongzhou Zhang, 2015). The government is also quick to point out that they have the legal basis to do so, even under the United Nations Convention on the Law of the Sea, which is highly regarded as part of customary international law (UNGA, 2008) . Furthermore, the United Nations General Assembly Resolution 62/177 deplored the fact that "illegal, unreported, and unregulated fishing constitutes a serious threat to fish stocks and marine habitats and ecosystems, to the detriment of sustainable fisheries as well as the food security and the economies of many states, particularly developing states." (United Nations, 2005). Referring to an official estimate, Indonesia faces an annual loss no less than US\$24 billion due to rampant illegal fishing by China, Malaysia, Philippines, Thailand, and Vietnam. The foreign ministry has repeatedly points out that every day, there are about 5,000 ships-mostly from neighboring Southeast Asian States and China - operating illegally in Indonesian waters, which constitutes a mockery out of the country's sovereignty.

The Global Maritime Axis strategy calls for a national efforts to regain control of Indonesia's maritime borders and to cooperatively eradicate IUU fishing. One significant step of Jokowi's administration to eliminate issues of fishing theft includes re-establishing, under his cabinet, the long-lost Coordinating Ministry for Maritime Affairs. It 
is then followed by the issuance of Presidential Regulation No. 16 Year 2017 regarding Indonesian Maritime Policy, which promulgates general guidelines of maritime policies and its implementations through variety of programs and activities, which are to be designed by relevant ministries and agencies in the maritime psyche. The outcome of such IUU fishing eradication policy is to see gradual rise of national fishery industries. However, the ultimate goal does not rest in the present sufficiency, rather the continuous spirit of Indonesian nationals as a whole, to work hand in hand in ensuring the sea's sustainability for the nation's generations to come. Therefore, Indonesia's bold action, as to sink and confiscate foreign vessels engaging in IUU Fishing, is indeed a rightful step to foster its maritime security.

\section{Strengthening Indonesia's Vulnerable Borders from Maritime Piracy and Robberies}

Maritime piracy and robberies have always been pertaining issue of maritime security. To date, attacks against commercial vessels remain frequent in Indonesian waters and sea-border areas, most notably Malacca Straits and South China Sea. For Indonesia, piracy is a domestic issue that can be tackled by internal measures without foreign interference. However, to safeguard the country's maritime territories, Indonesian government has recently established a new Maritime Security Agency named Indonesian Maritime Security Board (Badan Keamanan Laut Republik Indonesia, 'BAKAMLA'), to better coordinate joint sea patrols and rescue on Indonesia's territorial water. Its mission is to foster the realization of national and international maritime security which is able to guard the security and safety in the territorial sea and jurisdiction of Indonesia; therefore, BAKAMLA shall act as guards to the 'World's Maritime Axis' (Reveron, 2016). Protecting territorial sovereignty forms top priority of Indonesian foreign policy. For that purpose, Jokowi's administration appears determined to uphold territorial sovereignty against any intrusions which undermines Indonesia's territorial integrity and political independence. One significant move, which has been implored the current government is intensifying diplomacy to settle boundary disputes with its neighboring states.

Despite a relatively stable maritime environment in recent years, 
there are still unresolved maritime security issues which entails significant impact to the security and stability of Indonesia's maritime domain. Border disputes have been at the forefront of concern for Indonesian foreign and defense policy-makers. Recently Indonesia is involved in several territorial disputes, especially with regards to the escalating tension in the Natuna Waters, a reciprocal consequence to the long-standing dispute over the South China Sea. Hence, Jokowi's administration aims to intensify its maritime diplomacy to settle existing border disputes with its neighboring countries.

Picture 2: Indonesia's Maritime Border Dispute

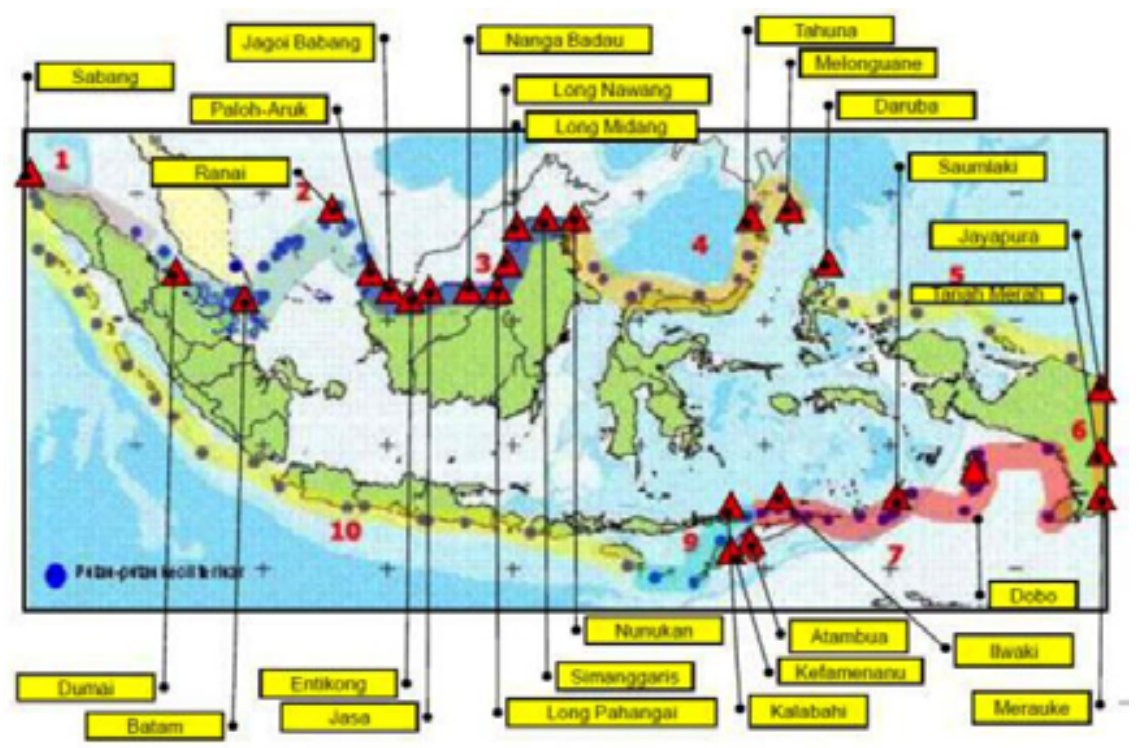

Indonesia's maritime diplomacy has resulted in some fruitful bilateral agreements between the archipelagic state and its closest neighbors such as Singapore, Malaysia and Philippines. Hence, on July $14^{\text {th }} 2017$, Indonesian government through the Coordinating Ministry for Maritime Affairs issued a new map of the Republic of Indonesia. This map serves as concrete evidence that Indonesia is actively strengthening its position in the international realm through concluding several maritime delimitation agreements, and finally scored an increase in its territorial waters. (Nirmala, 2017) 
Picture 2: New Map of the Republic of Indonesia

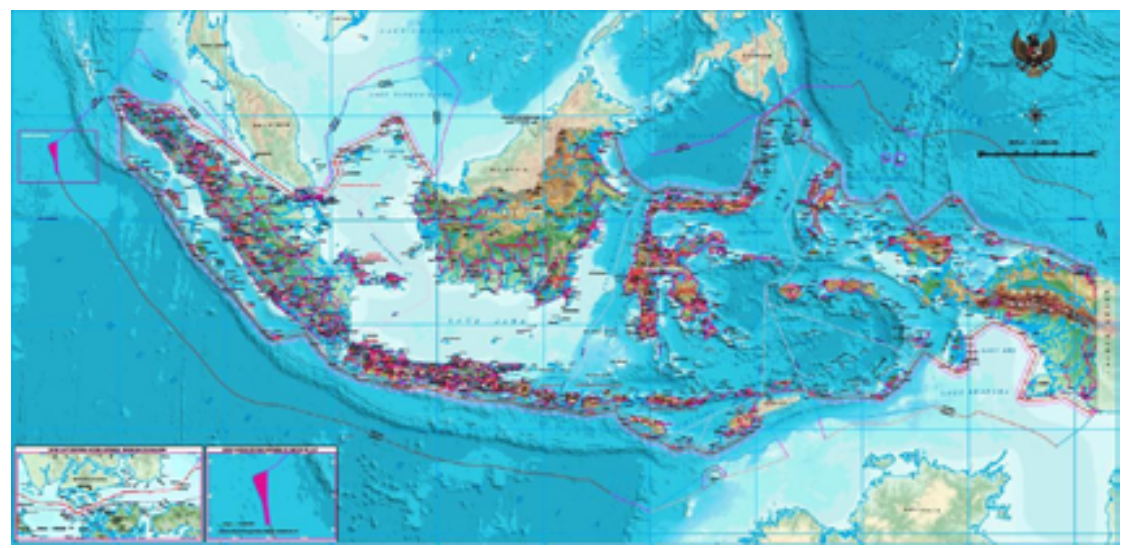

Source: Geospatial Information Agency, Republic of Indonesia, 2017

Recently Indonesia completed their maritime delimitation agreement with Singapore concerning the eastern and western parts of the Strait of Singapore, which is an inevitable pivotal point for international trade. The first agreement was in 1973 and has been ratified by Law No. 7 Year 1973, while the following agreements in 2009, has also been ratified by Law no.4 Year 2010. Now IndonesianSingapore maritime delimitation is completed and Indonesia successfully scored an increased water territory of water for 500 meters from Riau Strait. However, there is one point of maritime border dispute involving Indonesia, Singapore, and Malaysia. This issue becomes rather complicated due to Singapore-Malaysia 2008 dispute before the International Court of Justice concerning Pedra Branca. Noting that on June $30^{\text {th }}, 2017$, Malaysia filed an application for interpretation, Indonesia has not been able to set the maritime border with Singapore and Malaysia because they are still in dispute, so it must wait for the final decision of the Court before further bilateral negotiations take place.

The EEZ Boundary Agreement between Indonesia and the Philippines, which was signed in 2014 and recently ratified by the Law no.4 Year 2017, regulates the overlapping claims between the two states in Sulawesi Sea and the Philippine Sea. Both Indonesia and the Philippines realize the importance of setting a clear EEZ boundary limits to secure and manage their territory to the greatest 
prosperity for their people. Prior to the legalization of the EEZ agreement, there were many cases of illegal fishing in the EEZ, which is now recognized as Indonesia's region. Following the ratification of the said agreement, it is expected that cases of IUU fishing in Indonesia's outer islands will not happen again. Even if it is repeated, the government deserves their right to exercise legal actions in accordance to binding international law treaties.

Based on the Award of the International Arbitration on the South China Sea dispute between the Philippines and China, which revolves around the nine-dash-line claim, the Tribunal declared that very small islands and uninhabited reefs cannot be used as a basis to claim EEZ or continental shelf line as much as the 200 nautical miles (nm). As a consequence to the Tribunal's Award, China's Palau baseline claim was retreated, while Indonesia's EEZ increased in the northern part of the Halmahera Sea. In addition, the United Nations grants an additional area of approximately 4000 square kilometers in the southwest of Aceh; hence, now Indonesia's continental shelf stretches more than $200 \mathrm{~nm}$, pressing more against Malaysia. The government's struggle since 2009 has reaped in a fruitful result as the new map shows Indonesia's increased area of $\pm 100 \mathrm{~nm}$, or approximately the size of Madura Island. This makes Indonesia as the only Southeast Asian Country with EZZ more than $200 \mathrm{~nm}$. The remaining border dispute to settle is regarding Indonesia's continental shelf in northern Papua as well as the ones in southern part of Sumba Island (Ramadhan, 2017).

\section{Infrastructure Developments: Sea-Toll and Ports}

One key objective of Jokowi's doctrine is to build a sea-toll and upgrade port infrastructures, which will enhance inter-island connectivity and ultimately boost economic activities within the country. In the present status quo, Indonesia's coastline stretches to over 81 thousand kilometers, however it only has 694 ports. While Japan, with 34 thousand kilometers of coastline, has 3,000 ports. Noting to such concerns, there is a need for Indonesia to accelerate infrastructure developments agendas, such as by building port networks and marine infrastructure. Currently, the government has built 40 logistics centers in eastern and western Indonesia. These logistics centers are an integral part of the sea-toll construction 
project, which ultimately aims to build connectivity between farreaching regions in within Indonesia. Ought to the concern over the severe price gaps of daily needs between west and east Indonesia due to logistics hurdles, the establishment of sea-tolls acts as a breakthrough to standardize prices of goods and promote equality and social welfare. By early 2016, the government has completed 95 seaports and 4 ferry terminals scattered in Maluku, Papua, NTT and Sulawesi. Subsequently, there has been a 20 percent reduction in prices of basic goods at the respective areas.

\section{Revitalizing Indonesia's Maritime Court}

In accordance with the direction of President Joko Widodo, maritime security must be enforced through a legal adjudicating body. Hence, the presence of the Maritime Court, as a working unit under the Ministry of Transportation, which adjudicates ship accidents caused by the commission or absence of negligence of the crew's application of safety standard at sea, must be revitalized in order to keep up with the national doctrine. The revitalization of the Maritime Court must pay attention to existing legal basis regulating its activities, i.e. Law no. 17 of 2008 on Shipping and the Commercial Code (KUHD). It is truly an upsetting fact that, according to the Directorate General of Sea Transportation, out of 403 marine accidents happening in Indonesia from 2014 to 2016, only 85 cases were brought before the Maritime Court, with the remaining 6 pending cases. Currently, the Ministry of Transportation is still in the process of drafting a Presidential Regulation to strengthen the status of the Maritime Court, and is expected for issuance some time in 2017 (Kementerian Perhubungan, 2017)

\section{Conclusion and Recommendation}

As the world's largest archipelagic country, Indonesia's maritime ambition is certainly a logical policy direction. While expanding the Indonesian economy, the Jokowi administration will focus on maritime diplomacy and naval development as the key themes of the country's foreign and defense policy planning. President Widodo has repeatedly underlined that he will put national interests, including territorial sovereignty, above all else. Aside from a robust response to territorial intrusions, the new Indonesian 
government remains committed to peaceful means of resolving its border disputes. The government is urged to keep on intensifying bilateral dialogues to settle more maritime boundaries disputes with its neighbors. The doctrine of Global Maritime Axis has been a powerful political commitment for Indonesia. There are several concerns which the writer proposes in order to keep re-enforcing the brilliant concept. First, to manage governance and institutional arrangements, as to the status quo, marine sector is managed by at least by 16 ministries and state agencies which, at some points, creates legal uncertainty, and overlapping rules. Second, enhancement of maritime cooperation and efforts to address more border disputes, illegal fishing, sovereignty offenses, piracy and marine pollution with the emphasis that the seas should unite various nations and countries rather than separation. Third, formulating comprehensive agreements on marine security and its relations to trade as well as sustainability of the marine ecosystem and the wealth of natural resources and biodiversity. Fourth, strengthening our judicial authority to adjudicate cases of vessel collision, border infringement, and other similar illegal conducts through revitalizing Indonesia's Maritime Court. Lastly, enhance security defense through active border and security patrol that can act fast in responding breaches to our territorial sovereignty. 


\section{References}

\section{Journal}

Hongzhou, Zhang. 2015. "Indonesia's War on Illegal Fishing: Impact on China" in RSIS Commentary. Singapore: Nanyang Technological University.

Reveron, Derek. 2016. Maritime Security Deficits and International Cooperation: Illegal Fishing, Piracy, and Maritime Security Deficits in Southeast Asia. Washington DC: Georgetown University Press.

\section{UN Document}

United Nations. 2004. General Assembly, Concerned about World's Marine Ecosystems, Adopts Texts on Law of Sea, Sustainable Fisheries [online]. Available at http://www.un.org/press/en/2004/ ga10299. doc.htm (accessed on 17 October 2017).

UN General Assembly, Resolution 62/177. 2008. Sustainable Fisheries, Including through the 1995 Agreement for the Implementation of the Provisions of the United Nations Convention on the Law of the Sea of 10 December 1982 Relating to the Conservation and Management of Straddling Fish Stocks and Highly Migratory Fish Stocks, and Related Instruments [online]. Available at http://www.un.org/ en/ga/ search/view_doc.asp?symbol=A/RES/62/177 (accessed 21 October 2017).

\section{Online Article}

Kementerian Perhubungan. 2017. Indonesia sebagai Negara Maritim Terbesar di Dunia Perlu Mahkamah Pelayaran yang Kuat [online]. Available at http://dephub.go.id/post/read/indonesiasebagai-negara-maritim-terbesar-di-dunia-perlu-mahkamahpelayaran-yang-kuat (accessed on 20 October 2017).

Nirmala. 2017. Pertambahan Luas Laut Kita Dalam Peta Baru Indonesia [online]. Available at http://business-law.binus.ac. id/2017/07/31/pertambahan-luas-laut-kita-dalam-peta-baruindonesia/ (accessed on 17 October 2017)

Prianto, Agus. 2016. Konektivitas dan Logistik Poros Maritim [online]. 
Available at https://maritim.go.id/mewujudkan-mimpiindonesia-menjadi-poros-maritim-dunia/ (accessed on 16 October 2017).

Ramadhan, Bagus. 2017. Peta Indonesia Diperbaharui, Begini Perbandingannya dengan Peta Lama [online]. Available at https://www.goodnewsfromindonesia.id/2017/07/20/petaindonesia-diperbarui-begini-perbedaannya-dengan-yang-petalama (accessed on 17 October 2017).

Sekretaris Kabinet. 2017. Presiden Jokowi Teken Perpres Kebijakan Kelautan Indonesia [online]. Available at http://setkab.go.id/ presiden-jokowi-teken-perpres-kebijakan-kelautan-indonesia/ (accessed on 17 October 2017).

The Diplomat. 2016. Indonesia Blows up Intrepol's Most Wanted Ship [online]. Available at https://thediplomat.com/2016/03/ indonesia-blows-up-interpol-most-wanted-ship/ (accessed on 19 October 2017).

The Jakarta Globe. 2014. Indonesia Declares War on Illegal Foreign Fishing Boats [online]. Available at http://jakartaglobe.id/ news/indonesia-declares-war-illegal-foreign-fishing-boats/ (accessed on 17 October 2017).

The Jakarta Post. 2017. Jokowi's Global Maritime Axis Doctrine Key to Indonesia'sFuture[online].Availableathttps://www.pressreader. com/indonesia/the-jakarta-post/20170306/281633895027864 (accessed on 21 October 2017).

Witular, Rendi. 2014. Presenting Maritime Doctrine [online]. Available at http://www.thejakartapost.com/news/2014/11/14/ presenting-maritime-doctrine.html (accessed on 17 October 2017). 